\title{
Ankle Mortise
}

National Cancer Institute

\section{Source}

National Cancer Institute. Ankle Mortise. NCI Thesaurus. Code C117868.

A rectangular socket or bony arch that connects the ends of the tibia and fibula to the talus. 